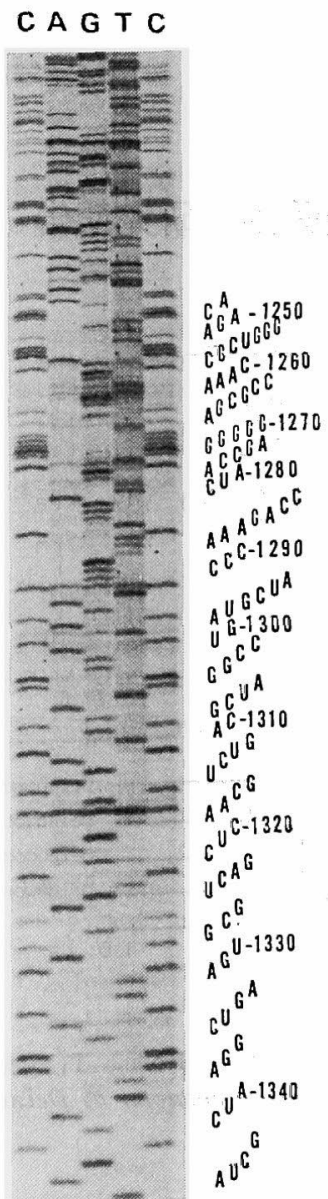

図 $416 \mathrm{~S}$ rRNA の逆転写酵素による迅速シーク エンシング

む.

2. 好熱性細菌 Thermomicrobium について, その系 統を調べた。この細菌はぺプチドグリカンを含有しない か゚, Eubacteria に属する細菌である. 16S rRNA の比 較から（図 3 ）この細菌はChloroflexus（緑色非硫黄細
菌の 1 種) と同じ系統に属し, らん藻, グラム陽性細菌, 紅色非硫黄細菌（purple nonsulfur bacteria）ょり以前 に分岐したと類推された。

3. $16 \mathrm{~S}$ rRNA の迅速シークエンス法を細菌の分類, 同定に適用した. 今回はPseudomonas 属を中心とした purple nonsulfur bacteria グループを対象として用い た. まず 8 種のプライマーDNA を合成した. これはリ ボゾーム RNA の 5 末端より 109-123, 342-357, 517531, 907-926, 1100-1115, 1392-1406，1495-1510, およ び 1525-1541 の部位に相補的なものである. これより最 も鮮明なシークエンスバンド（図 4) を与える 13921406 のプライマーを選び, このプライマーの上流 12201377 の部位を約 30 株の細菌でシークェンスした. この シークエンスの一次配列の相同性をKnuc で求め, これ に基づき UPGMA 法で采統樹を作成し, 系統分類学的 考察を行った. その結果, 分岐の時間を考慮した細菌の 系統関係が推定できた. しかし，これらの考察には，塩 基の違いの数だけでなく, 生物間での進化のモードの違 いも含めて検討すべきであると考劣られた。

な和，この研究はミュンヘン工科大 K. H. Schleifer 教授，ケール大 E. Stackebrandt 教授、イリノイ大 C. R. Woese 教授, 日本原子力研究所伊藤 均博士，東大 応微研駒形和男教授，小柳津矢恵子博士，平田愛子氏， 理化学研究所金子太吉博士との共同研究で行われた.

(1) H. Oyaizu, E. Stackebrandt, K. H. Schleifer, W. Ludwig, H. Pohla, H. Ito, A. Hirata, Y. Oyaizu and K. Komagata: A radiation-resistant rod-shaped bacterium, Deinobacter grandis gen. nov., sp. nov., with peptidoglycan containing ornithine, Int. J. Syst. Bacteriol., 37,62 (1987).

(2) H. Oyaizu, B. Debrunner-Vossbrinck, L. Mandelco, J. A. Studier and C. R. Woese : The green non-sulfur bacteria: A deep branching in the eubacterial line of descent, Syst. Appl. Microbiol., 9, 47 (1987).

\section{メタン生成細菌膜のエーテル型リン脂質および糖 脂螅とそれらの生合成前駆体の構造解析}

産業医科大学化学教室 古賀洋介

メタン生成細菌は好熱好酸菌, 高度好塩菌とともに古 細菌に属し, その特異な生化学的特徵は第三の生物群々 いう概念をますます明確に示してきた. エーテル型膜脂 質はこの特徽の中の重要なひとつである.メタン菌の脂 質の骨格は diphytanyl glycerol diether と dibiphytanyl diglycerol tetraether の 2 種類から成る. エーテル脂質 の膜の性質，生合成などを知るうえで，脂質の骨格構造 だけでなく，極性基部分まで含めた完全な構造の把握が 不可欠である. Methanobrevibacter arboriphilus 执よび Methanobacterium thermoautotrophicum のいくつかの 極性脂質の完全構造を決定したので，報告する.

M. arboriphilus $の$ phosphatidylserine のジェーテル 型アナログの各部分の立体構造を決めた. diphytanyl glycerol 部分は，旋光度を既知データと比較することに 
(a) PNL1a

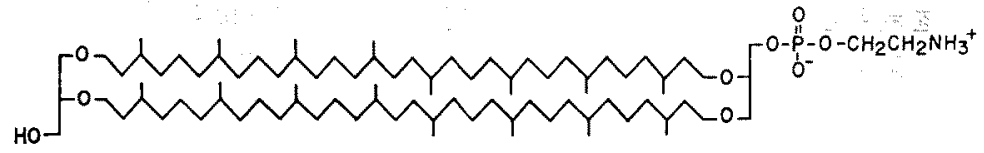

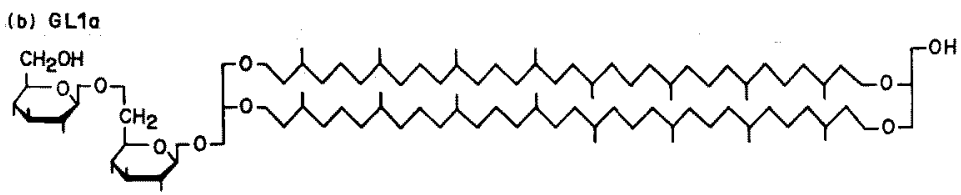

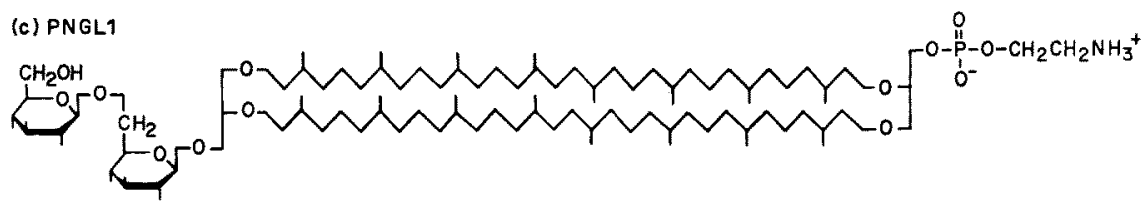

图 1

よって sn-2, 3-di ( $3^{\prime} \mathrm{R}, 7^{\prime} \mathrm{R}, 11^{\prime} \mathrm{R}, 15^{\prime}$-tetramethylhexadecyl) glycerol と判明した. serine は光学異性体分離 用液体クロマトダラフにより L-serine と決定しだ!

M. thermoautotrophicum の脂質の構造決定に先立 ここの菌からの脂質の抽出条件を検討し,トリク口ロ 酷酸酸性 Bligh \& Dyer 法が最適であることがわかっ た.この方法により従来の方法の 5 倍以上の脂質が抽出 されたそのなかのテトラェーテル型脂質の割合は従来 報告されている值より相当高かった。これ中性条件で はテトラェーテル型脂質の抽出が音わ好不十分であ り，酸栍条件でそれが注ぼ完全に抽出されることを示し ている. 極性脂質の TLC は少なくとも 23 種類の脂貿 の存在を示したそそれらの組成も合せて湘定した ${ }^{(2)}$.

M. thermoautotrophicum の3 種のテトラエーテル型 極性脂筫 (PNL $1 \mathrm{a} ，$ GL $1 \mathrm{a} ，$ PNGL1) を精製 した。 こ の3者の赤外吸収スペクトルを比較すると, PNGL 1 の スペクトルはPNL1a とGL1a のそれと考成したる のに相当していた. PNL 1 a, PNGL 1 の $\mathrm{BCl}_{3}$ 分解物の 水溶性生成物加ら glycerophosphoethanolamine 回収 した. 昰た， HF 分解によってこの 2 種の脂質から ethanolamine が得られた. PNGL1をメタノリンスす ると PNL1a となり、アセトりシスー弱了ルカリ分解与 るとGL1a となった。この3者のアセトリシスーメタノ リシス分解生成物は dibiphytanyl diglycerol tetraether であった. $\mathrm{BCl}_{3}$ 処理により生じる塩化アルキルは biphytanyl dichloride であった. 陰イオンモードの FAB マススベクトルにより，これらの分子量はそれぞれ， $1424 ， 1625 ， 1748$ であり，図1に示す構造式による分子 量と一致した．以上の結果からこの3 種の脂質の構造は
図1のとおりであると決定した。この3種の脂質に中性 脂質である diphytany! glycerol diether を加えて 4 種 1 組として quartet 脂質と文なした(3).

エーテル型脂質の呼び名には統一した名称が定まっ ていないので：ジアシル型リン脂質の phosphatidic acid になぞらえて archaetidic acid, caldarchaetidic acid，扣よびその誘導体として命名する準系統的な惯用 名老提案した(3).

本菌の対数增殖期培盖液に ${ }^{32} \mathrm{Pi}$ を加吝てリン脂質に in vivo で取り込むせ，リン脂質相互間の生合成的関係 を調べた、はとんど lag time なしに急速にラベルされ る 4 種類の脂質が見出された。これらはいずれもジエ ーテル型脂質で極性基としては phosphate, phosphoserine, phosphoinositol などをもっているものであっ

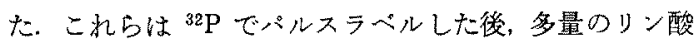
塩で ${ }^{32} \mathrm{P}$ を稀釈してチェイスすると急速な代謝回転を示 Lた

以上の結果により，M. thermoautotrophicum の極性 脂質全体の構造およびその生合成的関係を整理するため の現実的な基盤が整えられたといえる。

本研究に援助いたたいた(財)農芸化学研究奖励会に深 謝する。

(1) H. Morii and Y. Koga:Biochim. Biophys. Acta, 879, 103 (1986).

(2) M. Nishihara and Y. Koga: J. Biochem. 101, 997 (1987).

(3) M. Nishihara, H. Morii and Y. Koga: $J$. Biochem., 101, 1007 (1987).

(4) 末発表 